\title{
Virgibacillus arcticus sp. nov., a moderately halophilic, endospore-forming bacterium from permafrost in the Canadian high Arctic
}

\author{
Thomas D. Niederberger, Blaire Steven, Sophie Charvet, Beatrice Barbier \\ and Lyle G. Whyte
}

Correspondence

Lyle G. Whyte

lyle.whyte@mcgill.ca

\author{
Department of Natural Resource Sciences, McGill University, 21,111 Lakeshore Rd, Ste-Anne de \\ Bellevue, QC, Canada
}

\begin{abstract}
A novel, moderately halophilic, endospore-forming bacterial strain, designated $\mathrm{Hal} 1^{\top}$, was isolated from a permafrost core collected from the Canadian high Arctic. The temperature for growth of strain $\mathrm{Hal} 1^{\mathrm{T}}$ was $0-30{ }^{\circ} \mathrm{C}$ with no growth observed at either -5 or $37{ }^{\circ} \mathrm{C}$ (optimum growth at about $\left.25^{\circ} \mathrm{C}\right)$. Strain $\mathrm{Hal} 1^{\top}$ was able to grow at $\mathrm{NaCl}$ concentrations of $0-20 \%(w / v)$ and did not have an absolute $\mathrm{NaCl}$ requirement for growth; optimal growth was at $5 \%(\mathrm{w} / \mathrm{v}) \mathrm{NaCl}$. The level of $16 \mathrm{~S}$ rRNA gene sequence similarity between strain $\mathrm{Hal} 1^{\top}$ and the type strains of Virgibacillus carmonensis and Virgibacillus necropolis was $98.2 \%$; values with respect to the type strains of other recognized Virgibacillus species were below 96.0\%. The DNA G+C content of strain $\mathrm{Hal} 1^{\top}$ was 38.2 mol\%. Levels of DNA-DNA relatedness between strain Hal $1^{\top}$ and the type strains of $V$. carmonensis and $V$. necropolis were 14.0 and $21.0 \%$, respectively. The major fatty acid of strain $\mathrm{Hal} 1^{\top}$ was anteiso- $\mathrm{C}_{15: 0}$, consistent with species of the genus Virgibacillus. The cell-wall peptidoglycan of strain $\mathrm{Hal} 1^{\top}$ was type $\mathrm{A} 1 \alpha$ and the major respiratory quinone was MK-7. On the basis of genotypic and physiological results, strain $\mathrm{Hal} 1^{\top}$ (=DSM $19574^{\top}=$ JCM $14839^{\top}$ ) is proposed as the type strain of a novel species of the genus Virgibacillus, namely Virgibacillus arcticus sp. nov.
\end{abstract}

At the time of writing, the genus Virgibacillus comprised 14 recognized species (An et al., 2007; Chen et al., 2008; Heyndrickx et al., 1999; Heyrman et al., 2003; Hua et al., 2008; Lee et al., 2006a; Quesada et al., 2007; Yoon et al., 2004b, 2005; Wang et al., 2008). Members of the genus are Gram-positive, endospore-forming, motile rods and are taxonomically grouped within the order Bacillales (Garrity et al., 2007). As part of the microbial description of permafrost from the Canadian high Arctic (Steven et al., 2007), a number of halophilic media were tested in an attempt to isolate halophilic organisms identified in $16 \mathrm{~S}$ rRNA gene clone libraries. As a consequence a novel bacterial strain, Hal $1^{\mathrm{T}}$, was isolated from permafrost dated to be approximately 5000-7000 years old (Steven et al., 2007) at a depth of $9 \mathrm{~m}$ on quarter-strength halophiles moderate $(1 / 4 \mathrm{HM})$ medium adapted from Ventosa et al. (1982). Briefly, 1/4 HM medium was adapted by adding one-quarter (w/v) proteose-peptone, yeast extract and

Abbreviation: RAPD, randomly amplified polymorphic DNA.

The GenBank/EMBL/DDBJ accession number for the 16S rRNA gene sequence of strain $\mathrm{Hal} 1^{\top}$ is EF675742.

RAPD results from comparisons of strain $\mathrm{Hal} 1^{\top}$ and the type strains of recognized Virgibacillus species are available as supplementary material with the online version of this paper. glucose. The final composition of $1 / 4 \mathrm{HM}$ medium comprised (per litre): $178 \mathrm{~g} \mathrm{NaCl}, 2 \mathrm{~g} \mathrm{KCl}, 1 \mathrm{~g}$ $\mathrm{MgSO}_{4} \cdot 7 \mathrm{H}_{2} \mathrm{O}, 0.36 \mathrm{~g} \mathrm{CaCl}_{2} .2 \mathrm{H}_{2} \mathrm{O}, 0.23 \mathrm{~g} \mathrm{NaBr}, 0.06 \mathrm{~g}$ $\mathrm{NaHCO}_{3}, 0.01 \mathrm{~g} \mathrm{FeCl}_{3}, 1.25 \mathrm{~g}$ proteose-peptone, $2.5 \mathrm{~g}$ yeast extract and 0.25 g glucose, adjusted to about $\mathrm{pH}$ 7.0. Approximately $5 \mathrm{~g}$ of aseptically collected (Juck et al., 2005) permafrost (Steven et al., 2007) was added to $50 \mathrm{ml}$ of $1 / 4 \mathrm{HM}$ medium and incubated with shaking at 37,23 and $5{ }^{\circ} \mathrm{C}$. Growth was noted after 2 weeks incubation at $23{ }^{\circ} \mathrm{C}$ and after 1 month at $5{ }^{\circ} \mathrm{C}$. An aliquot of the enrichments was plated on $1 / 4 \mathrm{HM}$ plates, and single colonies were selected. Strain $\mathrm{Hal} 1^{\mathrm{T}}$ was the dominant colony type from both the 23 and the $5{ }^{\circ} \mathrm{C}$ enrichments as verified by sequencing a partial region of the $16 \mathrm{~S}$ rRNA gene $[100 \%$ sequence similarity identity by using primers 27F and 758R; see Steven et al. (2007) for PCR conditions and primer sequences]. DNA was isolated from a single colony of strain $\mathrm{Hal} 1^{\mathrm{T}}$ and the almost-complete $16 \mathrm{~S}$ rRNA gene was PCR amplified and sequenced as outlined by Steven et al. (2008). In brief, DNA was isolated by using the Gram-positive protocol of the DNeasy Tissue kit (Qiagen) and the 16S rRNA gene was PCR amplified and sequenced by using primers $27 \mathrm{~F}$ and 1492R (Lane, 1991).

The 16S rRNA gene sequence of strain $\mathrm{Hal} 1^{\mathrm{T}}$ showed highest similarity $(98.2 \%$ over $1350 \mathrm{bp})$ to both 
Virgibacillus necropolis LMG $19488^{\mathrm{T}} \quad$ (AJ315056) and Virgibacillus carmonensis LMG 20964 ${ }^{\mathrm{T}}$ (AJ316302); levels of 16S rRNA gene sequence similarity between strain Hal $1^{\mathrm{T}}$ and the type strains of other recognized Virgibacillus species were below $96 \%$, with closest matches to Virgibacillus halodenitrificans DSM $10037^{\mathrm{T}}$ and Virgibacillus marismortui $123^{\mathrm{T}}$ (95.9\% over $\left.1350 \mathrm{bp}\right) . V$. necropolis LMG $19488^{\mathrm{T}}$ and V. carmonensis LMG $20964^{\mathrm{T}}$ were obtained for subsequent comparisons, including API test strips, DNA-DNA hybridization, hydrolysis of a range of compounds, carbon utilization, $\mathrm{pH}$ growth range, antibiotic sensitivity and genotypic testing. The phylogenetic tree presented in Fig. 1 was based on an analysis of 1484 bp of aligned 16S rRNA gene sequences and indicates that strain Hal $1^{\mathrm{T}}$ formed a separate branch with $100 \%$ bootstrap support within the genus Virgibacillus. The tree was produced with the MacVector 7.0 software package (Oxford Molecular Ltd) by using the neighbour-joining method (Saitou \& Nei, 1987) with Jukes-Cantor modelling (Jukes \& Cantor, 1969). Similar topologies were also obtained by using the Tamura-Nei model (Tamura \& Nei, 1993) and UPMGA (unweighted pair-group method with arithmetic mean) distance estimation (results not shown). As a consequence, it was decided to characterize strain $\mathrm{Hal}$ $1^{\mathrm{T}}$ fully as it may represent a novel ancient lineage of Virgibacillus that has been trapped in permafrost for 50007000 years. Justification for the complete characterization of strain Hal $1^{\mathrm{T}}$ was also corroborated by preliminary results showing low temperature growth range and high salt tolerance as described in further detail below.

Table 1 provides a comparison of morphological and physiological traits between strain Hal $1^{\mathrm{T}}$ and the type strains of recognized Virgibacillus species. Unless otherwise noted, strain $\mathrm{Hal} 1^{\mathrm{T}}$ was routinely maintained and physiological tests were undertaken by using marine agar 2216 (MA; Difco), and cell morphology and motility were observed by using phase-contrast microscopy with a Nikon Eclipse E600 microscope. Hydrolysis of casein was tested by using growth on milk agar (Bacto) plates supplemented with skimmed milk power $\left(15 \mathrm{~g} \mathrm{l}^{-1}\right)$; methodologies are described below for the remainder of the experiments.

The colony colour of strain Hal $1^{\mathrm{T}}$ was light pink, distinctly different from that of both $V$. carmonensis and $V$. necropolis. Strain $\mathrm{Hal} 1^{\mathrm{T}}$ grew at $0-30{ }^{\circ} \mathrm{C}$, with optimum growth at about $25^{\circ} \mathrm{C}$; no growth was observed at 37 or $-5{ }^{\circ} \mathrm{C}$. Therefore, strain $\mathrm{Hal} 1^{\mathrm{T}}$ has a lower reported temperature range for growth than all recognized species of the genus Virgibacillus (Table 1). Strain Hal $1^{\mathrm{T}}$ also grew under anaerobic conditions, as determined by using an anaerobic chamber with an AnaeroGen sachet and appropriate anaerobic indicator (OXOID). Salt requirements for growth were tested in marine broth (Difco) and MA. Optimal growth was observed in the presence of $5 \%$ $\mathrm{NaCl}$ and weak growth was observed in media lacking $\mathrm{NaCl}$ and in the presence of $20 \% \mathrm{NaCl}$; no growth was

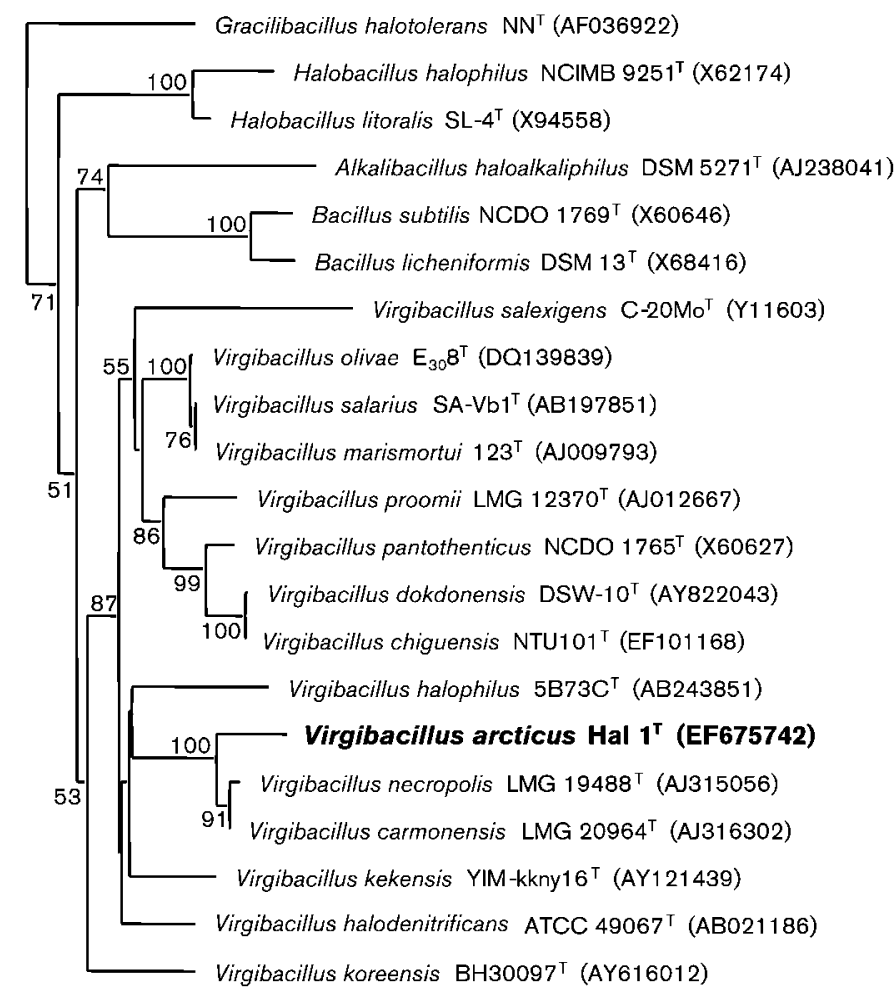

Fig. 1. Neighbour-joining phylogenetic tree showing the taxonomic position of strain $\mathrm{Hal}$ $1^{\top}$ based on 16S rRNA gene sequences. Values at nodes represent bootstrap percentages based on 1000 resamplings. The tree was rooted with Escherichia coli ATCC $11775^{\top}$ (accession no. X80725; not shown). Bar, 0.02 changes per nucleotide position. 
Table 1. Differential characteristics between strain $\mathrm{Hal} 1^{\top}$ and related Virgibacillus species

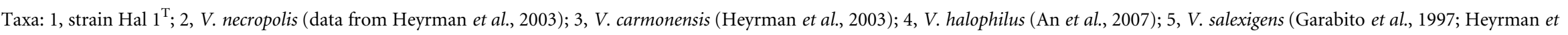

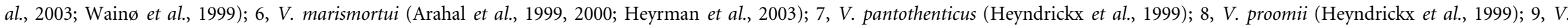

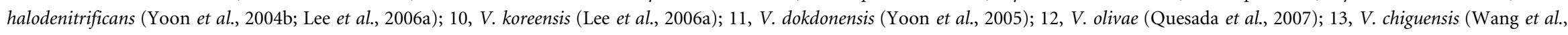

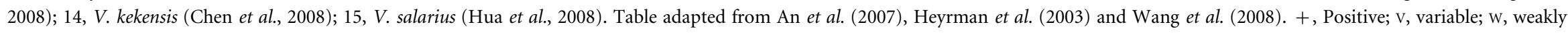
positive; -, negative; ND, not determined. All have MK-7 as the major menaquinone (not determined for $V$. olivae).

\begin{tabular}{|c|c|c|c|c|c|c|c|c|c|c|c|c|c|c|c|}
\hline Characteristic & 1 & 2 & 3 & 4 & 5 & 6 & 7 & 8 & 9 & 10 & 11 & 12 & 13 & 14 & 15 \\
\hline Pigmentation & Light pink & - & Pink & Yellow & - & - & - & - & - & - & - & Yellow & - & - & - \\
\hline Chains of cells & $\mathrm{v}$ & + & - & $\mathrm{ND}$ & + & + & + & + & + & - & $\mathrm{ND}$ & $\mathrm{v}$ & $\mathrm{ND}$ & - & + \\
\hline $\begin{array}{l}\text { Growth temperature } \\
\left({ }^{\circ} \mathrm{C}\right)\end{array}$ & $0-30$ & $10-40$ & $10-40$ & $5-45$ & $15-45$ & $15-50$ & $15-50$ & $15-50$ & $10-45$ & $10-45$ & $15-50$ & $20-45$ & $15-55$ & $10-50$ & $10-50$ \\
\hline Spore shape & $\mathrm{E}$ & E & $\mathrm{E}, \mathrm{S}$ & $\mathrm{E}$ & E & $\mathrm{E}$ & $\mathrm{E}, \mathrm{S}$ & $\mathrm{E}, \mathrm{S}$ & $\mathrm{E}$ & E & $\mathrm{E}, \mathrm{S}$ & $\mathrm{E}, \mathrm{S}$ & E, S & E, S & E $(S)$ \\
\hline Spore location $\dagger$ & $\mathrm{C}, \mathrm{S}$ & $\mathrm{C}, \mathrm{S}, \mathrm{T}$ & $S$ & $S$ & C, S, T & $\mathrm{S}, \mathrm{T}$ & $\mathrm{S}, \mathrm{T}$ & $\mathrm{S}, \mathrm{T}$ & $\mathrm{S}, \mathrm{T}$ & $\mathrm{T}$ & $\mathrm{S}, \mathrm{T}$ & $\mathrm{S}, \mathrm{T}$ & $\mathrm{S}, \mathrm{T}$ & $\mathrm{T}$ & $\mathrm{S}, \mathrm{T}$ \\
\hline Anaerobic growth & + & - & - & - & - & - & + & + & + & + & + & - & + & - & - \\
\hline \multicolumn{16}{|l|}{ Growth at: } \\
\hline $0.5 \% \mathrm{NaCl}$ & + & $\mathrm{W}$ & - & + & - & - & + & $\mathrm{W}$ & - & $\mathrm{W}$ & + & + & + & + & + \\
\hline $25 \% \mathrm{NaCl}$ & - & - & - & $\mathrm{ND}$ & $\mathrm{w}$ & + & - & - & $\mathrm{w}$ & - & - & $\mathrm{ND}$ & + & + & + \\
\hline $\mathrm{pH} 10$ & - & - & - & + & + & - & - & - & - & - & $\mathrm{ND}$ & - & - & + & + \\
\hline Nitrate reduction & + & + & + & + & - & + & $\mathrm{v}$ & - & + & - & - & + & + & + & - \\
\hline \multicolumn{16}{|l|}{ Hydrolysis of: } \\
\hline Casein & + & + & + & ND & + & + & + & + & + & $\mathrm{ND}$ & + & + & + & - & + \\
\hline Gelatin & + & $\mathrm{w}$ & - & + & + & + & + & $\mathrm{v}$ & + & - & + & + & + & - & $\mathrm{w}$ \\
\hline \multicolumn{16}{|l|}{ Acid production from: } \\
\hline D-Glucose & $\mathrm{w}$ & $\mathrm{w}$ & - & + & $\mathrm{w}$ & + & - & + & + & $\mathrm{w}$ & + & - & + & + & + \\
\hline D-Fructose & $\mathrm{w}$ & $\mathrm{w}$ & - & + & $\mathrm{w}$ & + & - & + & + & + & + & + & + & - & + \\
\hline D-Mannose & $\mathrm{w}$ & $\mathrm{w}$ & - & + & $\mathrm{W}$ & + & - & + & + & - & + & - & + & - & + \\
\hline Melibiose & + & - & - & - & $\mathrm{ND}$ & - & - & + & - & $\mathrm{ND}$ & - & $\mathrm{ND}$ & + & $\mathrm{ND}$ & - \\
\hline Trehalose & + & $\mathrm{w}$ & - & + & - & - & + & + & + & $\mathrm{w}$ & - & $\mathrm{ND}$ & - & $\mathrm{W}$ & - \\
\hline D-Mannitol & + & - & - & + & - & - & - & + & $\mathrm{v}(+) \ddagger$ & - & - & - & $\mathrm{W}$ & $\mathrm{W}$ & - \\
\hline $\begin{array}{l}\text { Major }(>10 \%) \text { fatty } \\
\text { acids (listed from high } \\
\text { to low concentration) }\end{array}$ & $\begin{array}{c}\text { anteiso- } \\
\mathrm{C}_{15: 0}\end{array}$ & $\begin{array}{c}\text { anteiso- } \\
\mathrm{C}_{15: 0} \\
\text { anteiso- } \\
\mathrm{C}_{17: 0}\end{array}$ & $\begin{array}{c}\text { anteiso- } \\
\mathrm{C}_{15: 0} \\
\text { anteiso- } \\
\mathrm{C}_{17: 0}\end{array}$ & $\begin{array}{c}\text { anteiso- } \\
\mathrm{C}_{15: 0} \\
\text { iso- } \mathrm{C}_{15: 0} \\
\text { anteiso- } \\
\mathrm{C}_{17: 0} \\
\text { iso- } \mathrm{C}_{16: 0}\end{array}$ & $\begin{array}{c}\text { iso- } \mathrm{C}_{15: 0} \\
\text { anteiso- } \\
\mathrm{C}_{15: 0}\end{array}$ & $\begin{array}{l}\text { iso- } \mathrm{C}_{15: 0} \\
\text { anteiso- } \\
\mathrm{C}_{15: 0}\end{array}$ & $\begin{array}{c}\text { anteiso- } \\
\mathrm{C}_{15: 0} \\
\text { anteiso- } \\
\mathrm{C}_{17: 0}\end{array}$ & $\begin{array}{c}\text { anteiso- } \\
\mathrm{C}_{15: 0} \text {, } \\
\text { anteiso- } \\
\mathrm{C}_{17: 0} \\
\text { iso- } \mathrm{C}_{15: 0}\end{array}$ & $\begin{array}{c}\text { anteiso- } \\
\mathrm{C}_{15: 0} \\
\text { anteiso- } \\
\mathrm{C}_{17: 0} \\
\text { iso- } \mathrm{C}_{16: 0}\end{array}$ & $\begin{array}{c}\text { anteiso- } \\
\mathrm{C}_{15: 0} \\
\text { iso- } \mathrm{C}_{16: 0}\end{array}$ & $\begin{array}{c}\text { anteiso- } \\
\mathrm{C}_{15: 0} \text {, iso- } \\
\mathrm{C}_{15: 0} \\
\text { anteiso- } \\
\mathrm{C}_{17: 0}\end{array}$ & $\begin{array}{l}\text { iso- } \mathrm{C}_{15: 0} \\
\text { anteiso- } \\
\mathrm{C}_{15: 0} \\
\text { iso- } \mathrm{C}_{17: 0}\end{array}$ & $\begin{array}{c}\text { anteiso- } \\
\mathrm{C}_{15: 0} \\
\text { anteiso- } \\
\mathrm{C}_{17: 0} \\
\text { iso- } \mathrm{C}_{15: 0}\end{array}$ & $\begin{array}{c}\text { anteiso- } \\
\mathrm{C}_{15: 0} \\
\text { iso- } \mathrm{C}_{14: 0}\end{array}$ & $\begin{array}{c}\text { iso- } \mathrm{C}_{15: 0} \\
\text { anteiso- } \\
\mathrm{C}_{15: 0}\end{array}$ \\
\hline Major polar lipids $§$ & $\begin{array}{l}\text { PG, DPG, } \\
\text { PLs }\end{array}$ & $\begin{array}{l}\text { PG, DPG, } \\
\text { PLs }\end{array}$ & $\begin{array}{l}\text { PG, DPG, } \\
\text { PE, PLs }\end{array}$ & $\mathrm{ND}$ & $\begin{array}{l}\text { PG, DPG, } \\
\text { PLs }\end{array}$ & $\begin{array}{c}\text { PG, } \\
\text { DPG, PLs }\end{array}$ & $\begin{array}{l}\text { PG, DPG, } \\
\text { PE, PLs }\end{array}$ & $\begin{array}{c}\text { PG, DPG, } \\
\text { PE, PLs }\end{array}$ & $\begin{array}{c}\text { PG, } \\
\text { DPG, PLs }\end{array}$ & $\begin{array}{l}\text { PG, DPG, } \\
\text { PLs }\end{array}$ & $\begin{array}{c}\text { PG, DPG, } \\
\text { PE, PLs }\end{array}$ & $\mathrm{ND}$ & $\begin{array}{l}\text { PG, DPG, } \\
\text { PE, PLs }\end{array}$ & $\begin{array}{l}\text { PG, DPG, } \\
\text { PLs }\end{array}$ & $\begin{array}{c}\text { PG, DPG, } \\
\text { PE, PLs }\end{array}$ \\
\hline Cell-wall type & $\mathrm{A} 1 \alpha$ & ND & ND $\quad n$ & meso-DAPS & meso-DAP & meso-DAP & meso-DAP & $\mathrm{ND}$ & meso-DAP & meso-DAP & meso-DAP & $\mathrm{ND}$ & meso-DAP & meso-DAP & meso-DAP \\
\hline $\begin{array}{l}\text { DNA G + C content } \\
(\mathrm{mol} \%)\end{array}$ & 38.2 & 37.3 & 38.9 & 42.6 & $36.3-39.5$ & $39.0-42.8$ & $36.9-38.3$ & $36.8-37.0$ & $38.0-39.0$ & 41.0 & 36.7 & 33.4 & 37.3 & 41.8 & 37.3 \\
\hline
\end{tabular}

${ }^{\star}$ E, Ellipsoidal; S, spherical.

$\dagger \mathrm{C}$, Central; S, subterminal; T, terminal.

N $\$$ Positive for the type strain.

$\stackrel{N}{N}$ §DPG, Diphosphatidylglycerol; PE, phosphatidylethanolamine; PG, Phosphatidylglycerol; PLs, unidentified phospholipids.

I meso-DAP, meso-Diaminopimelic acid. 
observed at $25 \% \mathrm{NaCl}$. Strain $\mathrm{Hal} 1^{\mathrm{T}}$ grew weakly without the addition of $\mathrm{NaCl}$, as determined on minimal salts medium supplemented with yeast extract $\left(50 \mathrm{mg} \mathrm{l}^{-1}\right)$ and glucose as sole carbon source (Greer et al., 1990). The $\mathrm{pH}$ range for growth was determined in $1 / 4 \mathrm{HM}$ with the $\mathrm{pH}$ adjusted prior to autoclaving, with the $\mathrm{pH}$ confirmed following autoclaving. Strain $\mathrm{Hal} 1^{\mathrm{T}}$ grew at $\mathrm{pH}$ 4.4-9.1; no growth was observed at $\mathrm{pH} 4.1$ or 9.5. In comparison, $V$. necropolis LMG $19488^{\mathrm{T}}$ and V. carmonensis LMG $20964^{\mathrm{T}}$ grew at $\mathrm{pH}$ 5.7-9.5 with no growth observed for these two taxa at $\mathrm{pH} 5.0$ or 10.1 .

Strain Hal $1^{\mathrm{T}}$ was catalase-positive, as determined by the addition of $3 \% \mathrm{H}_{2} \mathrm{O}_{2}$ to an active culture, with the production of bubbles indicating a positive reaction. Strain Hal $1^{\mathrm{T}}$ was oxidase-negative, as determined by using a $\mathrm{BD}$ BBL DrySlide according to the manufacturer's instructions (Becton Dickinson). The API 20E and API Staph strip test systems were used according to the manufacturer's instructions (bioMérieux). The type strains of $V$. necropolis and $V$. carmonensis were used as controls in these tests. Strain Hal $1^{\mathrm{T}}$ shared essentially the same API 20E profile as $V$. carmonensis with the exception of strong gelatinase activity. $V$. necropolis and $V$. carmonensis showed weak and no gelatinase activity, respectively, which is in accordance with the results reported by Heyrman et al. (2003). Various carbon substrates were screened in triplicate as described by Heyrman et al. (2003). Strain Hal $1^{\mathrm{T}}$ utilized both Dglucose and sucrose as sole carbon sources, but no growth was observed on D-lactose, cellobiose, melibiose or trehalose. The profile of carbon source utilization for strain Hal $1^{\mathrm{T}}$ differed from those of $V$. carmonensis and $V$. necropolis (Heyrman et al., 2003). Antibiotic sensitivity was tested by the addition of antibiotics to a final concentration of $100 \mu \mathrm{g} \mathrm{ml}^{-1}$ in MA medium. $V$. carmonensis, $V$. necropolis and strain $\mathrm{Hal} 1^{\mathrm{T}}$ did not grow in the presence of ampicillin, chloramphenicol, rifampicin, erythromycin and streptomycin. Antibiotic sensitivity data for other species of Virgibacillus have been documented only for Virgibacillus kekensis and Virgibacillus olivae (Quesada et al., 2007; Chen et al., 2008). Similarities to strain $\mathrm{Hal} 1^{\mathrm{T}}$ exist in that both $V$. kekensis and $V$. olivae were sensitive to ampicillin and rifampicin, $V$. kekensis was sensitive to chloroamphenicol ( $V$. olivae was resistant) and $V$. olivae was sensitive to erythromycin (not tested for $V$. kekensis) (Quesada et al., 2007; Chen et al., 2008). In contrast, V. kekensis was resistant to streptomycin (Chen et al., 2008) (not tested for V. olivae; Quesada et al., 2007). However, it should be noted that a standardized single disc method (Bauer et al., 1966) as used in the previous two studies was not utilized for the present study.

Fatty acids of strain Hal $1^{\mathrm{T}}$ were prepared from cells grown on MA for $48 \mathrm{~h}$ at room temperature and were identified by using the MIDI/Hewlett Packard Microbial Identification System (Sasser, 1990) at Keystone Laboratories, Edmonton, Canada. Fatty acids of strain Hal $1^{\mathrm{T}}$ comprising more than $1 \%$ of the total fatty acid content were iso- $\mathrm{C}_{14: 0}(5.84 \%)$, iso- $\mathrm{C}_{15: 0} \quad(1.78 \%)$, anteiso- $\mathrm{C}_{15: 0} \quad(80.93 \%), \quad$ iso- $\mathrm{C}_{16: 0} \quad(2.93 \%), \quad \mathrm{C}_{16: 0}$ $(1.56 \%)$ and anteiso- $\mathrm{C}_{17: 0}(2.78 \%)$. The fatty acid profile of strain $\mathrm{Hal} 1^{\mathrm{T}}$ was similar to those of the type strains of all recognized species of the genus Virgibacillus (see Table 1), in that strain $\mathrm{Hal} 1^{\mathrm{T}}$ shared the same dominant fatty acids and also possessed anteiso- $\mathrm{C}_{15: 0}$ as the major fatty acid. Specifically, the anteiso- $\mathrm{C}_{15: 0}$ content of the type strains of both $V$. carmonensis and V. necropolis (grown on MA) was also high, $65.54 \pm 1.4$ and $71.5 \%$ (Heyrman et al., 2003), respectively; the corresponding value for the type strains of all other Virgibacillus species is in the range 30.5$52.9 \%$ (data from An et al., 2007; Chen et al., 2008).

Analyses of the respiratory quinones, peptidoglycan and polar lipids were carried out by the identification service of the Deutsche Sammlung von Mikroorganismen und Zellkulturen (DSMZ) and Dr B. J. Tindall (DSMZ). Strain Hal $1^{\mathrm{T}}$ contained MK-7 as the major respiratory quinone $(100 \%)$, which fits the description of the genus Virgibacillus (Heyrman et al., 2003; and see Table 1). The major polar lipids were diphosphatidylglycerol, phosphatidylglycerol and two unidentified phospholipids, which is also typical for the genus Virgibacillus (Table 1). Strain Hal $1^{\mathrm{T}}$ did not contain any diaminopimelic acid isomers, with dinitrophenylation revealing that lysine was the only $\mathrm{N}$ terminal amino acid. Therefore, it was concluded that the peptidoglycan type of strain Hal $1^{\mathrm{T}}$ was $\mathrm{Al} \alpha$ (L-Lys direct, type A11 according to the DSMZ catalogue of strains). The presence of peptidoglycan type $A 1 \alpha$ is typically characteristic of genera of the Bacillus rRNA group 2 (Ash et al., 1991; Rheims et al., 1999; Stackebrandt et al., 1987) within the Bacillales; for example, the recently described Marinibacillus (Yoon et al., 2004a) and Jeotgabacillus (Yoon et al., 2001); however, peptidoglycan type Al $\alpha$ has also been detected for Bacillus seohaeanensis (Lee et al., 2006b) and the genera Sedimentibacter within the Clostridales (Breitenstein et al., 2002). Although the presence of cell-wall peptidoglycan type A1 $\alpha$ differs from recognized Virgibacillus species (Table 1), we recommend that strain $\mathrm{Hal} 1^{\mathrm{T}}$ is included within the genus Virgibacillus based on the results of other genotypic and phenotypic tests. As more representatives of Virgibacillus are identified and characterized, the peptidoglycan types characteristic of this genus may be better resolved.

DNA-DNA hybridization experiments between strain Hal $1^{\mathrm{T}}$ and the type strains of $V$. necropolis and $V$. carmonensis were undertaken by the DSMZ. DNA was isolated by using a French pressure cell and was purified by chromatography on hydroxyapatite (Cashion et al., 1977), and DNA-DNA hybridization was carried out as detailed by De Ley et al. (1970) under consideration of the modifications described by Huß et al. (1983). The level of DNA-DNA relatedness between strain $\mathrm{Hal} 1^{\mathrm{T}}$ and the type strains of $V$. necropolis and $V$. carmonensis was 21.0 and $14.0 \%$, respectively. This was corroborated by genome-based comparisons between strain Hal $1^{\mathrm{T}}$ and the type strains of $V$. necropolis and $V$. carmonensis by using randomly amplified polymorphic DNA (RAPD). RAPD analysis was undertaken by using 
two 9-nt random primers with the following sequences: primer 0944-10, 5'-AGAAGGCCG; primer 0940-12, 5' ACGCGCCCT (Miguez et al., 1997). The RAPD results are shown in Supplementary Fig. S1 and indicate obvious genotypic differences between strain $\mathrm{Hal} 1^{\mathrm{T}}$ and the type strains of $V$. carmonensis and $V$. necropolis. The $G+C$ content of strain $\mathrm{Hal} 1^{\mathrm{T}}$ was $38.2 \mathrm{~mol} \%$, as identified by triplicate assays via the fluorimetric melting temperaturebased method of Gonzalez \& Saiz-Jimenez (2002). All previously characterized type strains of species of the genus Virgibacillus have a DNA G $+\mathrm{C}$ content in the range 36.3$42.8 \mathrm{~mol} \%$ (Table 1 and references therein); the DNA $\mathrm{G}+\mathrm{C}$ content of strain Hal $1^{\mathrm{T}}$ is thus within the range reported for members of the genus Virgibacillus.

In summary, the morphology, 16S rRNA gene sequence, fatty acid profile and DNA G $+\mathrm{C}$ content of strain Hal $1^{\mathrm{T}}$ are characteristic of the genus Virgibacillus. However, physiological and genotypic results encompassing gelatinase activity, carbon substrate utilization, growth temperature, anaerobic growth, $\mathrm{pH}$ and temperature growth range, DNA-DNA relatedness and RAPD profiling indicate that strain Hal $1^{\mathrm{T}}$ represents a species of Virgibacillus separate from its closest phylogenetic relatives, namely $V$. carmonensis and $V$. necropolis. Therefore, we suggest that strain Hal $1^{\mathrm{T}}$ represents a novel species of the genus Virgibacillus, for which the name Virgibacillus arcticus sp. nov. is proposed.

As strain Hal $1^{\mathrm{T}}$ is not able to grow at subzero temperatures, it may not be considered to be an active member of the permafrost microbial community. However, given that it is moderately halophilic and endospore-forming, it is highly likely that it survived an extremely long period of time within the permafrost environment. This adds to current evidence that members of this bacterial genus are capable of surviving and being revived from extremely long periods of dormancy (Satterfield et al., 2005).

\section{Description of Virgibacillus arcticus sp. nov.}

Virgibacillus arcticus (arc'ti.cus. L. masc. adj. arcticus northern, Arctic, the place of origin of the type strain).

Gram-positive, motile rods $(0.5-0.8 \times 2-5 \mu \mathrm{m})$ occurring as single, paired or rarely as short chains of cells. Colonies are $2 \mathrm{~mm}$ in diameter after 1 week of incubation on $1 / 4$ $\mathrm{HM}$ at room temperature. Forms elliptical endospores, located centrally or subterminally. Capable of anaerobic growth. Growth occurs at $0-30{ }^{\circ} \mathrm{C}$, but no growth is observed at -5 or $37{ }^{\circ} \mathrm{C}$. Growth occurs from 0 to $20 \%$ $\mathrm{NaCl}$ (optimum, $5 \% \mathrm{NaCl}$ ); no growth occurs at $25 \%$ $\mathrm{NaCl}$. Grows between $\mathrm{pH} 4.4$ and 9.1 (optimum, about $\mathrm{pH}$ 7.0). Growth occurs on D-glucose and sucrose, but not on D-lactose, cellobiose, melibiose or trehalose as sole carbon source. Catalase-positive and oxidase-negative. Positive for hydrolysis of casein. In API 20E tests, positive for gelatinase and nitrate reduction, but negative for ONPG, arginine dihydrolase, lysine decarboxylase, ornithine decarboxylase, citrate utilization, $\mathrm{H}_{2} \mathrm{~S}$ production, urease, tryptophan deaminase, indole and the VogesProskauer reaction. Acid is not produced from inositol, Dsorbitol, L-rhamnose, sucrose, amygdalin or L-arabinose; acid is produced weakly from D-glucose, D-mannitol and melibiose. In API Staph tests, acid is produced from trehalose, D-mannitol, xylitol and melibiose; acid is produced weakly from D-glucose, D-fructose, D-mannose, maltose and lactose. Negative for production of alkaline phosphatase and acetyl-methyl-carbinol, and acid production from raffinose, xylose and sucrose. Acid is produced weakly from methyl $\alpha$-D-glucoside. Negative for $N$ acetylglucosamine, arginine dihydrolase and urease. Sensitive to ampicillin, chloramphenicol, rifampicin, erythromycin and streptomycin. Major fatty acids $(>1 \%)$ of the type strain are iso- $\mathrm{C}_{14: 0}$, iso- $\mathrm{C}_{15: 0}$, anteiso- $\mathrm{C}_{15: 0}$, iso$\mathrm{C}_{16: 0}, \mathrm{C}_{16: 0}$ and anteiso- $\mathrm{C}_{17: 0}$. The peptidoglycan and respiratory quinone types are $\mathrm{A} 1 \alpha$ and MK-7, respectively. Major polar lipids comprise diphosphatidylglycerol, phosphatidylglycerol and two unidentified phospholipids. The DNA G + C content of the type strain is $38.2 \mathrm{~mol} \%$.

The type strain, Hal $1^{\mathrm{T}}\left(=\mathrm{DSM} 19574^{\mathrm{T}}=\mathrm{JCM} 14839^{\mathrm{T}}\right)$, was isolated from a permafrost core of $9 \mathrm{~m}$ depth collected near Eureka, Ellesmere Island, in the Canadian high Arctic.

\section{Acknowledgements}

We would like to thank the NASA Ames drilling team for providing us with the opportunity to recover permafrost cores. Funding for this research was provided by the Natural Sciences and Engineering Research Council (NSERC), Canada Research Chair program (CRC), Canadian Foundation for Innovation (CFI), Northern Scientific Training Program (NSTP), Polar Continental Shelf Program (PCSP) and Canadian Space Agency (CSA) Canadian Analogue Research Network (CARN).

\section{References}

An, S.-Y., Asahara, M., Goto, K., Kasai, H. \& Yokota, A. (2007). Virgibacillus halophilus sp. nov., spore-forming bacteria, isolated from soil in Japan. Int J Syst Evol Microbiol 57, 1607-1611.

Arahal, D. R., Márquez, M. C., Volcani, B. E., Schleifer, K. H. \& Ventosa, A. (1999). Bacillus marismortui sp. nov., a new moderately halophilic species from the Dead Sea. Int J Syst Bacteriol 49, 521530.

Arahal, D. R., Márquez, M. C., Volcani, B. E., Schleifer, K. H. \& Ventosa, A. (2000). Reclassification of Bacillus marismortui as Salibacillus marismortui comb. nov. Int J Syst Evol Microbiol 50, 1501-1503.

Ash, C., Farrow, J., Wallbanks, S. \& Collins, M. (1991). Phylogenetic heterogeneity of the genus Bacillus as revealed by comparative analysis of small-subunit-ribosomal RNA sequences. Lett Appl Microbiol 13, 202-206.

Bauer, A. W., Kirby, W. M., Sherris, J. C. \& Turck, M. (1966). Antibiotic susceptibility by a standardized single disk method. Am J Clin Pathol 45, 493-496.

Breitenstein, A., Wiegel, J., Haertig, C., Weiss, N., Andreesen, J. \& Lechner, U. (2002). Reclassification of Clostridium hydroxybenzoicum as Sedimentibacter hydroxybenzoicus gen. nov., comb. nov., and 
description of Sedimentibacter saalensis sp. nov. Int J Syst Evol Microbiol 52, 801-807.

Cashion, P., Holder-Franklin, M. A., McCully, J. \& Franklin, M. (1977). A rapid method for base ratio determination of bacterial DNA. Anal Biochem 81, 461-466.

Chen, Y.-G., Cui, X.-L., Fritze, D., Chai, L.-H., Schumann, P., Wen, M.-L., Wang, Y.-X., Xu, L.-H. \& Jiang, C.-L. (2008). Virgibacillus kekensis sp. nov., a moderately halophilic bacterium isolated from a salt lake in China. Int J Syst Evol Microbiol 58, 647-653.

De Ley, J., Cattoir, H. \& Reynaerts, A. (1970). The quantitative measurement of DNA hybridization from renaturation rates. Eur $J$ Biochem 12, 133-142.

Garabito, M. J., Arahal, D. R., Mellado, E., Márquez, M. C. \& Ventosa, A. (1997). Bacillus salexigens sp. nov., a new moderately halophilic Bacillus species. Int J Syst Bacteriol 47, 735-741.

Garrity, G. M., Lilburn, T. G., Cole, J. R., Harrison, S. H., Euzéby, J. \& Tindall, B. J. (2007). Part 9 - The Bacteria: Phylum "Firmicutes": Class "Bacill" Taxonomic Outline of the Bacteria and Archaea, Release 7.76 March 2007.

Gonzalez, J. M. \& Saiz-Jimenez, C. (2002). A fluorimetric method for the estimation of $\mathrm{G}+\mathrm{C}$ mol\% content in microorganisms by thermal denaturation temperature. Environ Microbiol 4, 770-773.

Greer, C. W., Hawari, J. \& Samson, R. (1990). Influence of environmental factors on 2,4-dichlorophenoxyacetic acid degradation by Pseudomonas cepacia isolated from peat. Arch Microbiol 154, 317322.

Heyndrickx, M., Lebbe, L., Kersters, K., Hoste, B., De Wachter, R., Devos, P., Forsyth, G. \& Logan, N. A. (1999). Proposal of Virgibacillus proomii sp. nov. and emended description of Virgibacillus pantothenticus (Proom and Knight 1950) Heyndrickx et al. 1998. Int J Syst Bacteriol 49, 1083-1090.

Heyrman, J., Logan, N. A., Busse, H. J., Balcaen, A., Lebbe, L., Rodriguez-Diaz, M., Swings, J. \& Devos, P. (2003). Virgibacillus carmonensis sp. nov., Virgibacillus necropolis sp. nov. and Virgibacillus picturae sp. nov., three novel species isolated from deteriorated mural paintings, transfer of the species of the genus Salibacillus to Virgibacillus, as Virgibacillus marismortui comb. nov. and Virgibacillus salexigens comb. nov., and emended description of the genus Virgibacillus. Int J Syst Evol Microbiol 53, 501-511.

Hua, N.-P., Hamza-Chaffai, A., Vreeland, R. H., Isoda, H. \& Naganuma, T. (2008). Virgibacillus salarius sp. nov., a halophilic bacterium isolated from a Saharan salt lake. Int J Syst Evol Microbiol 58, 2409-2414.

Huß, V. A. R., Festl, H. \& Schleifer, K. H. (1983). Studies on the spectrophotometric determination of DNA hybridization from renaturation rates. Syst Appl Microbiol 4, 184-192.

Juck, D. F., Whissell, G., Steven, B., Pollard, W., McKay, C. P., Greer, C. W. \& Whyte, L. G. (2005). Utilization of fluorescent microspheres and a green fluorescent protein-marked strain for assessment of microbiological contamination of permafrost and ground ice core samples from the Canadian High Arctic. Appl Environ Microbiol 71, 1035-1041.

Jukes, T. H. \& Cantor, C. R. (1969). Evolution of protein molecules. In Mammalian Protein Metabolism, vol. 3, pp. 21-132. Edited by H. N. Munro. New York: Academic Press.

Lane, D. J. (1991). 16S/23S rRNA sequencing. In Nucleic Acid Techniques in Bacterial Systematics, pp. 115-175. Edited by E. Stackebrandt \& M. Goodfellow. Chichester: Wiley.

Lee, J. S., Lim, J. M., Lee, K. C., Lee, J. C., Park, Y. H. \& Kim, C. J. (2006a). Virgibacillus koreensis sp. nov., a novel bacterium from a salt field, and transfer of Virgibacillus picturae to the genus Oceanobacillus as Oceanobacillus picturae comb. nov. with emended descriptions. Int J Syst Evol Microbiol 56, 251-257.

Lee, J. C., Lim, J. M., Park, D. J., Jeon, C., Li, W. J. \& Kim, C. J. (2006b). Bacillus seohaeanensis sp. nov., a halotolerant bacterium that contains L-lysine in its cell wall. Int J Syst Evol Microbiol 56, 1893-1898.

Miguez, C. B., Bourque, D., Sealy, J. A., Greer, C. W. \& Groleau, D. (1997). Detection and isolation of methanotrophic bacteria possessing soluble methane monooxygenase (sMMO) genes using the polymerase chain reaction (PCR). Microb Ecol 33, 21-31.

Quesada, T., Aguilera, M., Morillo, J. A., Ramos-Cormenzana, A. \& Monteoliva-Sánchez, M. (2007). Virgibacillus olivae sp. nov., isolated from waste wash-water from processing of Spanish-style green olives. Int J Syst Evol Microbiol 57, 906-910.

Rheims, H., Frühling, A., Schumann, P., Rohde, M. \& Stackebrandt, E. (1999). Bacillus silvestris sp. nov., a new member of the genus Bacillus that contains lysine in its cell wall. Int J Syst Bacteriol 49, 795802.

Saitou, N. \& Nei, M. (1987). The neighbor-joining method: a new method for reconstructing phylogenetic trees. Mol Biol Evol 4, 406425.

Sasser, M. (1990). Identification of bacteria by gas chromatography of cellular fatty acids, MIDI Technical Note 101. Newark, DE: MIDI Inc.

Satterfield, C. L., Lowenstein, T. K., Vreeland, R. H., Rosenzweig, W. D. \& Powers, D. W. (2005). New evidence for $250 \mathrm{Ma}$ age of halotolerant bacterium from Permian salt crystal. Geology 33, 265268.

Stackebrandt, E., Ludwig, W., Weizenegger, M., Dorn, S., McGill, T. J., Fox, G. E., Woese, C. E., Schubert, W. \& Schleifer, K.-H. (1987). Comparative 16S rRNA oligonucleotide analyses and murein types of round-spore-forming bacilli and non-spore-forming relatives. J Gen Microbiol 133, 2523-2529.

Steven, B., Briggs, G., McKay, C. P., Pollard, W. H., Greer, C. W. \& Whyte, L. G. (2007). Characterization of the microbial diversity in a permafrost sample from the Canadian high Arctic using culturedependent and culture-independent methods. FEMS Microbiol Ecol 59, 513-523.

Steven, B., Chen, M. Q., Greer, C. W., Whyte, L. G. \& Niederberger, T. D. (2008). Tumebacillus permanentifrigoris gen. nov., sp. nov., an aerobic, spore-forming bacterium isolated from Canadian high Arctic permafrost. Int J Syst Evol Microbiol 58, 1497-1501.

Tamura, K. \& Nei, M. (1993). Estimation of the number of nucleotide substitutions in the control region of mitochondrial DNA in humans and chimpanzees. Mol Biol Evol 10, 512-526.

Ventosa, A., Quesada, E., Rodriguez-Valera, F., Ruiz-Berraquero, F. \& Ramos-Cormenzana, A. (1982). Numerical taxonomy of moderately halophilic Gram-negative rods. J Gen Microbiol 128, 1959-1968.

Wainø, M., Tindall, B., Schumann, P. \& Ingvorsen, K. (1999). Gracilibacillus gen. nov., with description of Gracilibacillus halotolerans gen. nov., sp. nov.; transfer of Bacillus dipsosauri to Gracilibacillus dipsosauri comb. nov., and Bacillus salexigens to the genus Salibacillus gen. nov., as Salibacillus salexigens comb. nov. Int J Syst Bacteriol 49, 821-831.

Wang, C.-Y., Chang, C.-C., Ng, C. C., Chen, T.-W. \& Shyu, Y.-T. (2008). Virgibacillus chiguensis sp. nov., a novel halophilic bacterium isolated from Chigu, a previously commercial saltern located in southern Taiwan. Int J Syst Evol Microbiol 58, 341-345.

Yoon, J. H., Weiss, N., Lee, K. C., Leem, I. S., Kang, K. H. \& Park, Y. H. (2001). Jeotgalibacillus alimentarius gen. nov., sp. nov., a novel bacterium isolated from jeotgal with L-lysine in the cell wall, and reclassification of Bacillus marinus Rüger 1983 as Marinibacillus marinus gen. nov., comb. nov. Int J Syst Evol Microbiol 51, 2087-2093. 
Yoon, J. H., Kim, I. G., Schumann, P., Oh, T. K. \& Park, Y. H. (2004a). Marinibacillus campisalis sp. nov., a moderate halophile isolated from a marine solar saltern in Korea, with emended description of the genus Marinibacillus. Int J Syst Evol Microbiol 54, 1317-1321.

Yoon, J. H., Oh, T. K. \& Park, Y. H. (2004b). Transfer of Bacillus halodenitrificans Denariaz et al. 1989 to the genus Virgibacillus as
Virgibacillus halodenitrificans comb. nov. Int J Syst Evol Microbiol 54, 2163-2167.

Yoon, J. H., Kang, S. J., Lee, S. Y., Lee, M. H. \& Oh, T. K. (2005). Virgibacillus dokdonensis sp. nov., isolated from a Korean island, Dokdo, located at the edge of the East Sea in Korea. Int J Syst Evol Microbiol 55, 1833-1837. 